J. Management and Humanity Research

Vol. 2, 2020, 65-81

ISSN: 2582-7766 (online)

Published on 25 January 2020

www.researchmathsci.org

DOI: http://dx.doi.org/10.22457/jmhr.v02a06206
Journal of

Management and

Humanity Research

\title{
The Mechanism and Early-warning Value of ICT Enterprise Prosperity Index Based on Accounting Information
}

\author{
Zhi Liu ${ }^{1^{*}}$ and Yutong Feng ${ }^{2}$ \\ School of Economics and Management \\ Chongqing University of Posts and Telecommunications \\ Chongqing - 400065, Chongqing, China. \\ ${ }^{1}$ E-mail: 648630588@,qq.com; ${ }^{2}$ E-mail: liwei-cqu@163.com
}

Received 5 December 2019; accepted 12 January 2020

\begin{abstract}
All the time, the financial early warning research has been concerned by scholars at home and abroad, it can provide Suggestions for the normal operation of enterprises and investment decisions of investors, has great reference value, and has achieved many results at present. However, the early-warning mechanism based on accounting information is not mature, and the research combining ICT specific enterprise background is very limited.

The research content of this paper includes the following three parts. First, prepare the ICT business climate index, used to form this article for the financial crisis early warning is the most important predictor variable, adopted by the basic idea of enterprise boom index based on the accounting index, index of the sample is a random sample of 31 listed ICT companies, one of the be ST listed companies there are 10, to verify this to build early warning prediction accuracy of the model. Secondly, a financial crisis regression model is built based on enterprise prosperity index and other control variables to determine whether the forecasting variables such as enterprise prosperity index have significant forecasting effect on the occurrence of financial crisis (by ST). The Logistic regression model is adopted. Finally, this paper analyzes the prediction accuracy of the financial warning model, and summarizes the research conclusions.

It is found that the ICT enterprise prosperity index compiled in this paper has a significant prediction effect on the occurrence of financial crisis (by ST), and the prewarning model constructed can successfully predict the financial crisis of ICT listed companies at the accuracy level of $66.7 \%$.
\end{abstract}




\section{Zhi Liu and Yutong Feng}

Keywords: Finance, Prosperity Index, warning system, accounting

\section{Introduction}

The prosperity index (PI), also known as prosperity, is a quantitative description of entrepreneurs' qualitative judgement centered on the situation of prosperity variations in the process of prosperity survey, which is used to present the development status of macro economy and the business situation and its future development. The generation and construction of the prosperity index is based on the enterprise prosperity survey, which originated from Germany after the Second World War, and later France, the United Kingdom, Australia and other countries have gradually begun to discuss the research and application development of the enterprise boom survey (HUANG, 2013).

Since the 1990s, the world economy has been in the doldrums, whose main reason is that we do not have enough information to make a warning and cannot respond in advance to the crisis that will occur. At present, China is in the period of economic and social reform and transformation. During this period, China's economic development will be affected by more and more complicated factors, such as income levels and industrial structure and so on. The financial early-warning system can signal a financial crisis before the occurrence of financial crisis in the enterprise operation. It can prevent or prepare countermeasures in advance, and can also find defects in the company's management system and make timely adjustments to avoid the company facing financial problems. The financial early-warning mechanism can also provide a measure of measuring business performance for normal business enterprises., the following business strategy can be adjusted based on which, and also provide a basis for operational crisis prevention. Therefore, the financial early-warning mechanism has a significant value in the operation and development of all enterprises. It allows companies to be confidant in their operations and make timely responded measures according to the information they have learned. However, ICT companies have a profound impact on China's development. Therefore, research on ICT companies allows us to make use of the function of early-warning mechanisms to avoid the crisis of development.

\section{Literature review}

\subsection{Prosperity index}

In foreign countries, some scholars of Paris Statistical Conference in 1888 used four colors to measure the economic fluctuations of France from 1877 to 1881. Since then, scholars from various countries have paid attention to this field and started research and confirmation on the index. In 1909, the United States first released the Babson Economic Activity Index. Later, the "U.S. General Business Index", established by the Harvard University, had a far-reaching impact on the research of prosperity index. It was compiled based on the time difference of indicators. And the selected ones are divided into three 
The Mechanism and Early-warning Value of ICT Enterprise Prosperity Index Based on Accounting Information

different categories, and three indexes are synthesized. The index accurately predicts the four economic fluctuations of the United States in the 20th century. however, it was abandoned because it did not predict the great economic crisis. Later, the United States released the Diffusion Index (DI) and the Composite Index (CI). American scholars Stoke and Watson made use of the state space model proposed by Tanizaki Kushiro (1993) to propose the S-W boom index. The IFO Institute of Germany conducts research on various business sectors related to business every month. After obtaining a large amount of research data, it has obtained an IFO business prosperity index that has a significant impact on the German business sector(Shi, 2020).

In China, the research involved in the economic prosperity index was only started in 1980s. Initially, the National Information Department applied for an analysis of China's economic prosperity and began to organize more people to participate in macroeconomic research(Hong,2011), and issued an economic early-warning system in line with China's situation in the same year. Which was piloted in the national economic information system based on the previous research on macroeconomic in the early 1991. At present, the main prosperity index researched in China can be divided into three categories according to the research scope(Yi, 2010). One is a relatively comprehensive enterprise in all industries released by the National Bureau of Statistics. One is industry prosperity index suggesting a specific situation of enterprise economics, which can predict the development trend of an industry; the last one is business boom index referring to a business economic situation, which can be used to determine whether there is a crisis for business managers and other information users. Among them, the "National Housing prosperity Index" is very popular in China's real estate industry(Feng, 2005). In later studies, some scholars used the multivariate statistical model method to establish China's economic leading indicators and consistent indicators, which constructed a prosperity index, and then built China's macro quarterly monitoring and early-warning system standardized by GDP(Zeng,2016). Some scholars have studied the 29 indicators of the central bank and calculated six diffusion indices based on the characteristics of the indicators to reflect the production and operation of the enterprises from different aspects; the main prosperity index in China can be divided into three categories according to time differences, which is used as a basis to do some calculations.

\subsection{The analysis of early-warning model.}

The establishment of early-warning model is comparatively mature. At present, the main research of early-warming can be divided into three methods.

The first one is univariate early-warning analysis. The univariate model is a variable which regards the financial indicator of the enterprise as a early warning model. At first, a 


\section{Zhi Liu and Yutong Feng}

financial index of Fitzatrick Company is quite different between the financially distressed company and the normal company, and thus it is presented that the financial ratio may reflect the development trend of enterprise in the future, which suggests that this indicator can be used to predict the development of the enterprise(Ning, 2013). Then Beaver proposed a univariate financial early-warning model that predicts the company's development in the future with a single financial index. The univariate financial earlywarning model is established based on a relatively single financial variable which indicates whether there are financial difficulties with the company. and find that the accuracy of the operational capital debt ratio and total net profit margin forecast is the highest.

The second one is multivariate early-warning analysis. Since the univariate earlywarning model can't reflect the condition of the enterprise with only one indicator, the research using this model may not be able to effectively predict whether the company will have a financial crisis(Li-ming, 2004). Therefore, multivariate model is proposed by people because multiple financial variables can be selected to predict the possibility, whose effect may be more comprehensive and more in line with the actual situation, and based on this, an early-warning model is established. In the model of this early warning analysis, the Zscore model is widespreadly used in the dominant position. In which, the Z-values are calculated based on the five indexes obtained by the calculation of the enterprise accounting information to determine whether there are possibilities of financial crisis, the lower the $\mathrm{Z}$ value, the more likely it is to go bankrupt $(\mathrm{Li}, 2020)$.

The last one is the early-warning study combined with introductions of other relevant theories. Some scholars have presented that under certain recurring conditions, disaster theory can predict the structural drift of the company's stock returns when the company issues an announcement, which shows that disaster theory can be used to forecast the likely of corporate bankruptcy(Collier, 2015; Collier, 2015). Some scholars have applied the option to the financial early-warning model. The results indicate that the face value of the debt at maturity and the market value of the current enterprise can better predict whether the enterprise is in danger of bankruptcy. From the perspective of corporate governance theory, some studies have shown that the concentration of ownership of enterprises will also have an impact on the financial status of the company. If the shareholding ratio of large shareholders is too high, the majority shareholders will choose to sacrifice the interests of minority shareholders to achieve their own interests(Shellman,2007). And the excessively dispersed equity will result in shareholders' insufficient supervision to the operators, which is not conducive to decision-making. Using historical historical events to analyze, it is found that the audit opinion of the company's annual report is also related to whether the company has a financial crisis. The audit opinion also has a certain effect on the bankruptcy or financial distress probability. 
The Mechanism and Early-warning Value of ICT Enterprise Prosperity Index Based on Accounting Information

3. Method for compiling enterprise prosperity index based on accounting indicators 3.1. Accounting information on which the enterprise prosperity index is compiled

The basic accounting information that needs to be based on the preparation of the enterprise prosperity index includes the three aspects shown in Table 1, namely the three basic contents of the financial statements.

Table 1: Accounting information on which the enterprise prosperity index is compiled

\begin{tabular}{c|l}
\hline (1) & $\begin{array}{l}\text { Major accounting statement data such as balance sheet, income statement, } \\
\text { cash flow statement, statement of changes in financial position, and schedule } \\
\text { data; }\end{array}$ \\
\hline (2) & $\begin{array}{l}\text { Data in daily accounting information, such as data recorded in the books of } \\
\text { accounts and not directly reflected in the main accounting statements and } \\
\text { schedules; }\end{array}$ \\
\hline (3) & $\begin{array}{l}\text { Financial ratio calculated based on major accounting statements, schedules, } \\
\text { and daily accounting data. }\end{array}$ \\
\hline
\end{tabular}

According to the financial statements listed in Table 1, we can collect the indicators needed for the construction of the model, and divide them into the leading indicators, the synchronous indicators and the lagging indicators, and compile the leading index, the synchronization index or the lagging index respectively(Wuzhao,2013). These three types of indicators can comprehensively reflect the different time nodes and different types of enterprise capabilities, and provide a reference for us to understand its current status and development trends in the future. The financial indicators with the aforementioned characteristics can make the index compiled by us realistically reflect the condition of the enterprise. In this way, when we test the validity of the model, the data is consistent with the actual situation, and the test results are also reliable.

\subsection{Accounting indicators and weights compiled by the enterprise prosperity index}

The enterprise prosperity is a description of the company's current potential and the development of next stage. In this paper, we have selected various financial indicators that can reflect the company's profitability, operational capability, solvency, and development capabilities to construct a business climate index. These indicators can not only reflect the current state of the enterprise, but also to some extent the future development of the enterprise and its connection with the outside, and selected two of the financial indicators reflecting the various capabilities of the enterprise, a total of 8 indicators to develop a 


\section{Zhi Liu and Yutong Feng}

prosperity index. These eight indicators can comprehensively reflect the ability of enterprises to repay debts, the ability to obtain profits, the ability to operate normally, and the ability to develop in the future. They can comprehensively reflect the overall ability of enterprises, so the enterprise climate index compiled with these eight indicators accords comparatively with the actual situation of the enterprise, it is more reasonable to make the next warning study for us with these dates.

Refer to the basic indicators of performance evaluation and their weights clearly defined as 《State-owned Capital Performance Evaluation Rules》 in the 1999, and screen the data to determine the financial indicators and corresponding weights needed to compile the ICT Enterprise prosperity Index. Table 2 shows.

Table 2: Enterprise Prosperity Measured by Financial Indicators and Weights

\begin{tabular}{llcc}
\hline \multirow{2}{*}{ Indicatortype (weight) } & \multicolumn{3}{c}{ Specific indicators } \\
\cline { 2 - 4 } Solvency (0.22) & Name & Code & Weight \\
& Quick ratio & QR & 0.12 \\
\multirow{2}{*}{ Profitability (0.42) } & Assets and liabilities & DAR & 0.1 \\
& Operating profit margin & OPR & 0.12 \\
\multirow{2}{*}{ Operating capacity (0.18) } & Rate of total assets returns & RTAR & 0.30 \\
& Receivable turnover of account & RTR & 0.09 \\
& Total asset turnover & TAT & 0.09 \\
\multirow{2}{*}{ Development ability (0.18) } & Total assert growth rate & TAGR & 0.09 \\
& Net profit growth rate & NPR & 0.09 \\
\hline
\end{tabular}

\subsection{Formulation of enterprise prosperity index}

The preparation of the prosperity index is mainly used for the construction of the enterprise financial early-warning system. Therefore, what we mainly calculate is the prosperity index of individual industries which is weighted average weighted by the selected financial indicators of the company based on the given weight, calculated as

$$
\mathrm{EPI}=\frac{\sum \text { Single financial indicator index } \times \text { Financial indicator weights }}{\text { Sum of weights }}
$$

The prosperity index of each enterprise at a specific time is related to the importance of its financial indicators and indicators. Therefore, each enterprise prosperity index is calculated by the same indicators in the same period based on the weights we have determined.

\subsection{Data acquisition}

31 listed companies were selected from 631 ICT companies by random sampling. According to the relevant data, we can know that the model constructed in this paper has a 
The Mechanism and Early-warning Value of ICT Enterprise Prosperity Index Based on Accounting Information

very high accuracy rate for financial crisis forecasting after one year. Therefore, the earlywarning model of this paper is to study whether the company's financial data in 2016 can be used to judge whether the company is ST in 2017, so the following 31 companies' financial indicators were selected and the prosperity index was compiled. The financial indicators required for the preparation of the prosperity index are all sourced from Eastern Fortune Network.

\subsection{Calculation results of ICT enterprise prosperity index}

According to the calculation formula shown in the column, the calculation function of Excel is used to calculate various indicators that comprehensively reflect the capabilities of the enterprise, and finally the following calculation results are obtained.

Table 3: The enterprise prosperity index in 2016

\begin{tabular}{|c|c|c|c|c|c|}
\hline $\begin{array}{l}\text { Securities } \\
\text { code }\end{array}$ & $\begin{array}{l}\text { Securities short } \\
\text { name }\end{array}$ & $\begin{array}{l}\text { Enterprise } \\
\text { prosperity } \\
\text { index }\end{array}$ & $\begin{array}{l}\text { Securities } \\
\text { code }\end{array}$ & $\begin{array}{l}\text { Securities } \\
\text { short name }\end{array}$ & $\begin{array}{l}\text { Enterprise } \\
\text { prosperity } \\
\text { index }\end{array}$ \\
\hline 002072 & Kerry & 4.914622 & 300386 & $\begin{array}{l}\text { Flying } \\
\text { integrity }\end{array}$ & 1.851755 \\
\hline 603888 & Xinhua Net & 111.103873 & 300393 & $\begin{array}{l}\text { Zhonglai } \\
\text { shares }\end{array}$ & 6.889793 \\
\hline 002138 & $\begin{array}{l}\text { Sunlord } \\
\text { Electronics }\end{array}$ & 12.937115 & 300496 & $\begin{array}{l}\text { Zhongke } \\
\text { Chuangda }\end{array}$ & 0.807278 \\
\hline 002261 & $\begin{array}{l}\text { Tuowei } \\
\text { Information }\end{array}$ & 9.815262 & 300578 & $\begin{array}{l}\text { Fair } \\
\text { communicati } \\
\text { on }\end{array}$ & 13.399793 \\
\hline 300042 & $\begin{array}{l}\text { Netac } \\
\text { Technology }\end{array}$ & 0.810008 & 600884 & Shanshan & 4.589033 \\
\hline 002384 & $\begin{array}{l}\text { Dongshan } \\
\text { Precision }\end{array}$ & 2.997937 & 002194 & $\begin{array}{ll}* \text { ST } & \text { Van } \\
\text { Valley } & \end{array}$ & 1.500419 \\
\hline 002464 & Public connection & 10.521850 & 600198 & ST Datang & -0.047792 \\
\hline 002587 & Alto Electronics & 3.796559 & 600680 & *ST Shangpu & -0.758680 \\
\hline 002815 & $\begin{array}{l}\text { Chong } \\
\text { Technology }\end{array}$ & 7.622440 & 600074 & ST Bao Qian & 2.098813 \\
\hline 002845 & Tongxingda & -0.778666 & 600289 & *ST ICT & -2.153059 \\
\hline 600677 & $\begin{array}{l}\text { Aerospace } \\
\text { communication }\end{array}$ & 21.704695 & 600462 & $\begin{array}{ll}\text { ST } & \text { nine } \\
\text { shares } & \end{array}$ & -0.003271 \\
\hline
\end{tabular}




\begin{tabular}{lllllll}
\multicolumn{7}{c}{ Zhi Liu and Yutong Feng } \\
000606 & Successfully dost & 11.575709 & 600634 & $*$ ST & rich & 2.455387 \\
& & & & control & \\
300139 & Xiaocheng & 4.503114 & 600654 & ST & -0.668311 \\
& Technology & & & Zhongshan & \\
300183 & Neusoft carrier & 1.175961 & 600701 & *ST Gongxin & 1.181189 \\
300275 & Mei Ansen & -0.337835 & 600767 & ST Yunsheng & -0.579487 \\
300323 & Huacan & 32.793908 & & & \\
& Optoelectronics & & & & \\
\hline
\end{tabular}

Judging from the calculated prosperity index, the overall enterprise prosperity index of the financial healthy enterprises in 2017 is larger than that of the financially abnormal enterprises in 2016. That is to say, the calculated prosperity index in the financially sound enterprises is larger, which is consistent with the actual situation, so we can conclude that the calculated results can be used for the next financial early-warning analysis.

\section{Financial early-warning model based on enterprise prosperity index}

\subsection{Sample selection}

Since the construction of the financial early-warning model is symbolized by the enterprise prosperity index, the sample of this part of the study is still 31 ICT companies which have compiled the prosperity index. Looking at the current domestic financial early-warning research, we can find that the symbol of most early-warning models distinguishing whether a company is facing the financial crisis is whether it is ST or not. In which the ST companies has a financial crisis and the non-ST companies are financially normal. Therefore, this paper selects the financial indicators of 21 non-ST companies and 10 ST companies in 2017 ICT companies to build models. Specifically, using data of enterprise prosperity in 2016 and ST or non-ST in 2017 is to construct and verify the early-warning model.

In the design of early-warning model, this paper adopts the most representative method in the existing research, namely, constructing Logistic regression model, which takes the occurrence of financial crisis as the dependent variable and the business climate index and other control variables as predictors.

\subsection{Forecast indicators}

Regarding the enterprise prosperity index of 31 sample companies in 2016 as basic predictive variables and referring to relevant literature. It is found that combining financial indicators with non-financial indicators can lead to more accurate predictions. Therefore, this paper selected some financial indicators and non-financial indicators which are closely relevant to the enterprise early-warning model in existing researches to finally constructed the variable system of the early-warning analysis in this paper, as shown in Table 4. 
The Mechanism and Early-warning Value of ICT Enterprise Prosperity Index Based on Accounting Information

Table 4: The variables of financial early-warning model

\begin{tabular}{clcl}
\hline $\begin{array}{c}\text { Indicator } \\
\text { type }\end{array}$ & Indicator name & $\begin{array}{c}\text { Serial } \\
\text { number }\end{array}$ & \multicolumn{1}{c}{ Calculation formula } \\
\hline & Prosperity index & X1 & - \\
& Cash flow ratio & $\mathrm{X} 2$ & $\begin{array}{l}\text { Net cash flow from operating activities } \\
/ \text { current liabilities }\end{array}$ \\
& Debt guaranteed & $\mathrm{X} 3$ & $\begin{array}{l}\text { Net cash flow from operating activities } \\
\text { / total debt }\end{array}$ \\
& rate & Xperating income & $\begin{array}{l}\text { Net cash flow from operating activities } \\
\text { / operating income }\end{array}$ \\
& $\begin{array}{l}\text { Net cash flow from } \\
\text { operating activities } \\
\text { per share }\end{array}$ & X5 & $\begin{array}{l}\text { Net cash flow from operating activities } \\
\text { / total number of shares }\end{array}$ \\
\hline
\end{tabular}

Table 4: The variables of financial early-warning model(continued)

\begin{tabular}{|c|c|c|c|}
\hline $\begin{array}{l}\text { Indicator } \\
\text { type }\end{array}$ & Indicator name & $\begin{array}{l}\text { Serial } \\
\text { number }\end{array}$ & Calculation formula \\
\hline \multirow{5}{*}{$\begin{array}{l}\text { Non-financial } \\
\text { indicator }\end{array}$} & Board size & X6 & Number of board members \\
\hline & $\begin{array}{l}\text { Ratio of independent } \\
\text { directors }\end{array}$ & $\mathrm{X} 7$ & $\begin{array}{l}\text { Number of independent } \\
\text { directors / number of board } \\
\text { members }\end{array}$ \\
\hline & Number of boards & $\mathrm{X} 8$ & $\begin{array}{l}\text { The shareholding ratio of the } \\
\text { largest shareholder }\end{array}$ \\
\hline & $\begin{array}{l}\text { Number of shareholders } \\
\text { meeting }\end{array}$ & X9 & Number of board meetings \\
\hline & Litigation arbitration & $\mathrm{X} 10$ & $\begin{array}{l}\text { Major litigation arbitration } \\
\text { occurred: } 1 \text {; otherwise: } 0\end{array}$ \\
\hline
\end{tabular}


Zhi Liu and Yutong Feng

\begin{tabular}{lll} 
External guarantee $\quad \mathrm{X} 11$ & $\begin{array}{l}\text { Major external guarantees } \\
\text { occurred: } 1 \text {; otherwise: } 0\end{array}$ \\
\hline
\end{tabular}

As seen from table 4, the factors affecting the financial crisis of the enterprise proposed in the existing literature involve various aspects, such as cash flow, board of directors, arbitration and guarantee There may be internal correlation or even linear correlation between these indicators. Therefore, factor analysis of these indicators is needed to determine the final financial crisis predictor variables.

\subsection{Predictors}

\section{(1) KMO test}

Table 5: The table of KMO test and Bartlett spherical test result

\begin{tabular}{|l|l|l|}
\hline \multicolumn{3}{|c|}{ KMO and Bartlett's inspection } \\
\hline Sampling enough Kaiser-Meyer-Olkin metrics & .600 \\
\hline \multirow{4}{*}{ Bartlett's sphericity test } & $\begin{array}{l}\text { Approximate } \\
\text { chi-square }\end{array}$ & 240.960 \\
\cline { 2 - 3 } & $\mathrm{df}$ & 78 \\
\cline { 2 - 3 } & Sig. & .000 \\
\hline
\end{tabular}

We can see from Table 5 that the calculation result of KMO selected in this paper is 0.6 , so the 11 variables selected in this paper are suitable for factor analysis. We can use factor analysis to obtain a representative comprehensive factor.

\section{(2) Extracting the main component}

Table 6 is a eigenvalue and variance contribution table in which the five principal components analyzed by the variables are arranged according to the eigenvalue size. The variance contribution of the common factor $\mathrm{Fj}$ represents the sum of the variance contributions provided by the same common factor $\mathrm{Fj}$ for all variables, which is an indicator of the relative importance presenting the common factor. It can be seen from the table that the five principal components F1-F5 extracted by orthogonal rotation have an information coverage rate of $85.827 \%$ for the original index, which is still ideal.

Table 6: The table Interpretation of variance 
The Mechanism and Early-warning Value of ICT Enterprise Prosperity Index Based on Accounting Information

\begin{tabular}{|c|c|c|c|c|c|c|c|c|c|}
\hline \multirow{2}{*}{$\begin{array}{l}\text { Ingre } \\
\text { dients }\end{array}$} & \multicolumn{3}{|c|}{ Initial eigenvalue } & \multicolumn{3}{|c|}{ Extract square and loading } & \multicolumn{3}{|c|}{ Rotation square and loading } \\
\hline & Total & Variance $\%$ & Accumulation \% & Total & Variance $\%$ & Accumulation \% & Total & Variance \% & Accumulation \% \\
\hline 1 & 4.165 & 37.860 & 37.860 & 4.165 & 37.860 & 37.860 & 3.148 & 28.619 & 28.619 \\
\hline 2 & 1.552 & 14.105 & 51.965 & 1.552 & 14.105 & 51.965 & 1.994 & 18.127 & 46.747 \\
\hline 3 & 1.367 & 12.424 & 64.389 & 1.367 & 12.424 & 64.389 & 1.671 & 15.189 & 61.936 \\
\hline 4 & 1.334 & 12.130 & 76.519 & 1.334 & 12.130 & 76.519 & 1.456 & 13.235 & 75.171 \\
\hline 5 & 1.024 & 9.308 & 85.827 & 1.024 & 9.308 & 85.827 & 1.172 & 10.656 & 85.827 \\
\hline 6 & .627 & 5.698 & 91.526 & & & & & & \\
\hline 7 & .472 & 4.294 & 95.819 & & & & & & \\
\hline 8 & .234 & 2.126 & 97.945 & & & & & & \\
\hline 9 & .143 & 1.303 & 99.248 & & & & & & \\
\hline 10 & .080 & .724 & 99.972 & & & & & & \\
\hline 11 & .003 & .028 & 100.000 & & & & & & \\
\hline
\end{tabular}

Table 7: The table of Principal component analysis

\begin{tabular}{llllll}
\hline & \multicolumn{5}{c}{ Ingredients } \\
\cline { 2 - 6 } & $\mathbf{1}$ & $\mathbf{2}$ & $\mathbf{3}$ & $\mathbf{4}$ & $\mathbf{5}$ \\
\hline X1 & 0.226 & 0.062 & 0.059 & 0.882 & -0.168 \\
X2 & 0.889 & -0.29 & 0.155 & 0.174 & 0.067 \\
X3 & 0.874 & -0.3 & 0.16 & 0.012 & 0.141 \\
X4 & 0.846 & -0.262 & 0.254 & -0.038 & -0.166 \\
X5 & 0.778 & 0.06 & -0.19 & 0.126 & -0.122 \\
X6 & 0.156 & -0.064 & 0.771 & 0.512 & -0.139 \\
X7 & -0.058 & 0.173 & -0.916 & 0.157 & 0.016 \\
X8 & -0.253 & 0.908 & -0.159 & -0.02 & 0.048 \\
X9 & -0.231 & 0.844 & -0.086 & 0.001 & 0.139 \\
X10 & 0.039 & 0.233 & -0.039 & -0.183 & 0.862 \\
X11 & 0.276 & 0.345 & 0.222 & -0.541 & -0.556 \\
\hline
\end{tabular}

According to the factor load and principal component analysis results in Table 7, it can be concluded that:

(1) The first factor F1 is mainly determined by the variable X1 (Enterprise Prosperity Index) reflecting the prosperity situation of the enterprise;

(2) The second factor F2 has a larger load value of 1 in X2, X3, X4 and X5, so it is explained by four variables: X2 (cash flow ratio), X3 (debt guarantee rate), X4 (net cash flow per operating activity) and X5 (business income cash ratio debt guarantee), mainly reflecting the cash flow of the enterprise, so the factor F2 is named as cash flow capability; 


\section{Zhi Liu and Yutong Feng}

(3) The third factor F3 has a relatively larger load value in X6 and X7, which is mainly explained by the two variables of X6 (board size) and X7 (independent director ratio) ,reflecting the structure of the company's board of directors, so the factor F3 is named as the board structure;

(4) The fourth factor F4 has a relatively larger load value in X8 and X9, which is mainly explained by the two variables X8 (number of board meetings) and X9 (number of shareholders held), which reflects the frequency of corporate meetings. Therefore, the factor F4 is named as the communication frequency.

(5)The fifth factor F5 is determined by the variable X11 (external guarantee) and X10 (suit arbitration), mainly reflecting the role of third-party institutions, so it is named as third-party participation.

The five common factors mentioned above have extracted most of the data contained in the original variables, so we can directly use these five variables for analysis in the next regression model.

\subsection{Early-warning model fitting results based on logistic regression}

(1) Regression fitting results

Through the preparation of the previous enterprise prosperity index, the financial indicators which measures the cash flow of the company and several other non-financial indicators, and factor analysis, we use 6 indicators as the explanatory variables of Logistic regression, and use spss 17.0 for logic regression analysis. After verifying and comparing the various variables into the model, this paper selects the backward strategy of the seven methods to screen out the variables with insignificant financial warning effect, and finally constructs the financial early- warning model by using the five factors obtained by factor analysis. The parameters of the model are fitted as shown in Tables 8 and 9:

Table 8: Regression result

\begin{tabular}{|c|c|c|c|c|c|c|c|c|c|}
\hline & lable & B & S.E, & Wals & df & Sig. & Exp & $\begin{array}{l}\text { the } 95 \\
\operatorname{EXP}(B\end{array}$ & of C.I. \\
\hline & & & & & & & & Upper & Lower \\
\hline $\begin{array}{l}\text { Step } \\
1 \mathrm{a}\end{array}$ & $\begin{array}{l}\text { Cash flow } \\
\text { ability }\end{array}$ & 1.411 & 0.529 & 7.118 & 1 & 0.008 & 4.098 & 1.454 & 11.552 \\
\hline & $\begin{array}{l}\text { Board } \\
\text { structure }\end{array}$ & -1.341 & 0.647 & 4.3 & 1 & 0.038 & 0.262 & 0.074 & 0.929 \\
\hline & $\begin{array}{l}\text { Communi } \\
\text { cation } \\
\text { frequency }\end{array}$ & 0.963 & 0.918 & 1.099 & 1 & 0.292 & 2.619 & 0.433 & 15.845 \\
\hline
\end{tabular}


The Mechanism and Early-warning Value of ICT Enterprise Prosperity Index Based on Accounting Information

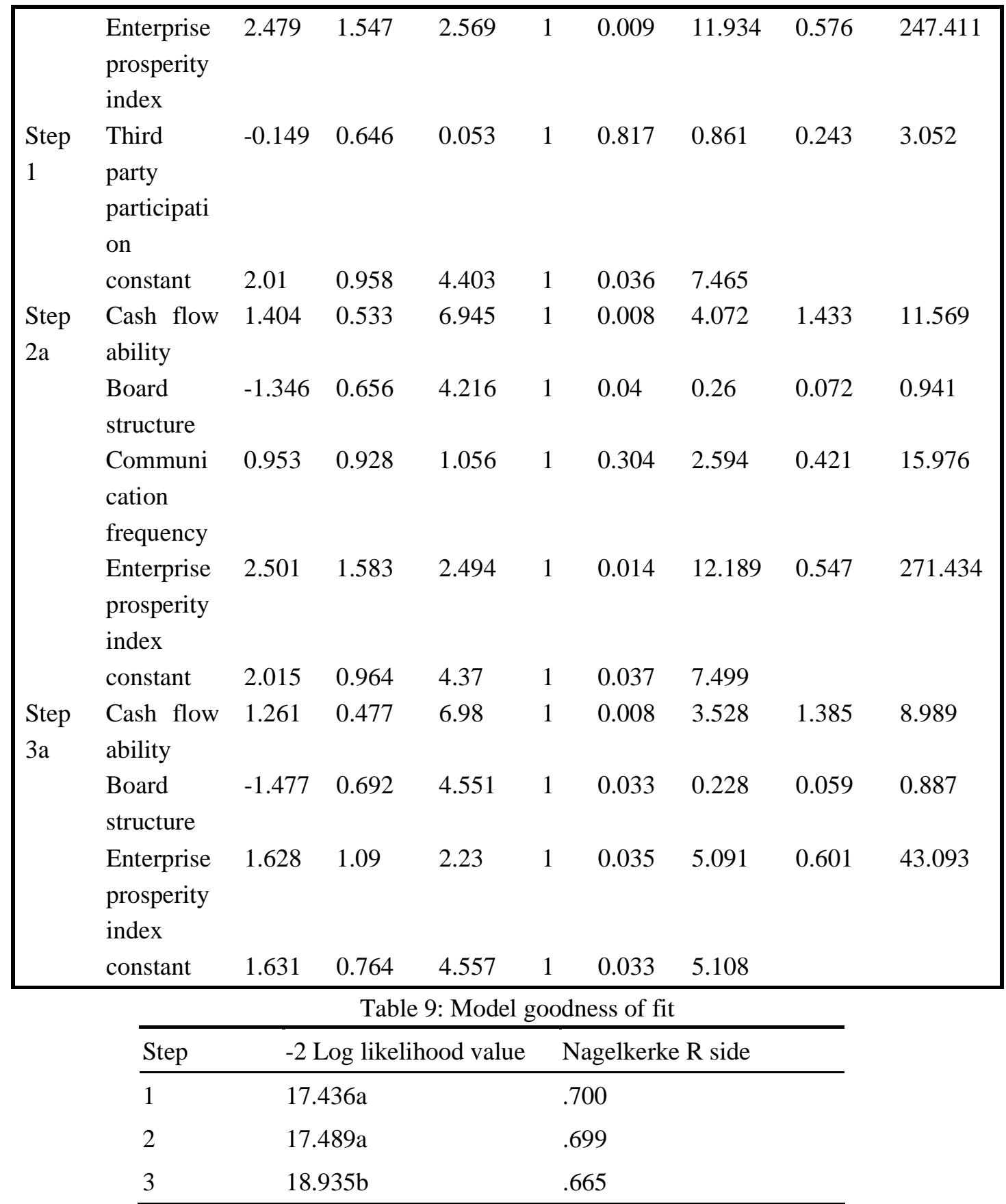

From the above table 9 , we can derive the regression equation of this paper:

$$
\left\{\begin{array}{c}
P=\frac{e^{y}}{1+e^{y}} \\
Y=1.631+1.261 F 1-1.477 F 2+1.628 F 3
\end{array}\right.
$$




\section{Zhi Liu and Yutong Feng}

Based on the above analysis results, we can see that Logistic regression analysis uses the five main factors to further extract three predictive variables which have a greater impact on the model, namely: the company's cash flow capacity, corporate communication frequency and business climate index.

According to the model we have established, we can see that the predictive variable enterprise prosperity index and the company's cash flow ability have a negative relationship with the company's probability of financial distress, and the frequency of corporate communication is in the same direction, which means that the greater the enterprise cash flow capacity and the enterprise prosperity index, the less likely the company is to have a financial crisis. The more frequent the company's communication, the more likely it is that the company will experience a financial crisis.

In addition, the model goodness-of-fit results in Table 9 show that the R-squared value (goodness of fit) of Model 3 reaches 66.5\%, which indicates that the forecasting effect (degree of interpretation) of a company's financial crisis of independent variables included in the final regression model (4.1) obtained in this paper can reach 66.5\%.

\section{(2) Early warning effect of the model}

In this paper, we define $\mathrm{Y}=1$ as a non-ST enterprise and $\mathrm{Y}=0$ as an ST enterprise. Considering that in the sample selection, the selection ratio of ST company and non-ST company is about $1: 2$. In this case, we choose 0.5 as our demarcation point, that is, when $\mathrm{P}$ is greater than $95 \%$, judge a financial crisis will occur; conversely, when $\mathrm{P}$ is less than $95 \%$, the financial is judged to be normal. The larger the value calculated using this model, the greater the likelihood that the company will face financial risk; the smaller the value, the better the company's financial position. In the case where the critical value is determined to be $95 \%$, the classification prediction values of the model are as shown in the table: 
The Mechanism and Early-warning Value of ICT Enterprise Prosperity Index Based on Accounting Information

Table 10: Classification table

\begin{tabular}{|c|c|c|c|c|c|c|}
\hline & & & & & Obs & \\
\hline & & & & & Z & Dorati. \\
\hline & & & & ST & No ST & \\
\hline Step 1 & Z & ST & 8 & & 2 & 80.0 \\
\hline & & Not-ST & 1 & & 20 & 95.2 \\
\hline & & ntage & & & & 90.3 \\
\hline Step 2 & Z & ST & 8 & & 2 & 80.0 \\
\hline & & Not-ST & 1 & & 20 & 95.2 \\
\hline & & ntage & & & & 90.3 \\
\hline Step 3 & Z & ST & 8 & & 2 & 80.0 \\
\hline & & Not-ST & 0 & & 21 & 100.0 \\
\hline & & ntage & & & & 93.5 \\
\hline
\end{tabular}

From Table, we can clearly see that after 3 steps, the accuracy of the model prediction constructed by this paper gradually increases, finally reaching $93.5 \%$. Accurately judged that 20 financially normal enterprises will not have a financial crisis after one year; Two companies are mistakenly judged to be financial normal after one year, and the accuracy of prediction is $80 \%$; the overall prediction accuracy of this model reached $93.5 \%$. Therefore, we can think that the model can effectively judge whether the company will have a financial crisis after one year.

\section{Conclusion}

The research in this paper is carried out based on the results of financial early-warning analysis, factor analysis and logistic regression analysis of domestic and foreign scholars. In the actual analysis process, this paper takes 31 listed ICT companies in China (including 21 non-ST companies and ST companies) as the research samples to construct the prosperity index of China's ICT enterprises, and uses the enterprise prosperity index combining with financial indicators which measures the cash flow capacity of enterprises and other non-financial indicators to effectively monitor the financial crisis of ICT companies through factor analysis and logistic regression analysis. The research results include the following two aspects.

First, the preparation of the enterprise prosperity index is based on eight indicators that reflect the capabilities of all aspects of the enterprise. In the construction of the financial early- warning model, this paper uses compiled enterprise prosperity index and 


\section{Zhi Liu and Yutong Feng}

financial indicators measuring the company's cash flow capacity, as well as the nonfinancial indicators such as company's audit situation, violations, board structure to more fully display the company's business development.

Secondly, we take the five predictive variables extracted by factor analysis with collected and calculated index as the basis for constructing the Logistic early-warning model, and normalized feature vector is obtained by calculating with factor load matrix. The feature vector and the original data variable normalization matrix is calculated to obtain five standardized predictors, based on which the logistic regression analysis is carried out. After three parameters fitting, three predictive variables are extracted. Finally, the accuracy of the model construction reached 66.5. \%.

\section{REFERENCES}

1. P.M.Collier, Accounting for managers: Interpreting accounting information for decision making, John Wiley \& Sons, (2015).

2. G.Feng, The Review on Real Estate Early Warning System. Journal of Guizhou University (Natural Science), 4 (2005) 9.

3. H.Hong, A study on establishing Guangdong Insurance prosperity index, Insurance Studies, 11 (2011) 10.

4. X.B.Huang, C.M.Cao and P.Zhu, Research on Enterprise Prosperity Index Based on Accounting Information: Based on the Data of Chinese Listed Companies From 2007 to 2012. Journal of Nanjing Audit University, 5 (2013) 8.

5. J.Li, X.Wan and B.Lai, Research on risk early-warning system of transitional operation of Africa-related enterprises, African Journal of Business Management, 14(2) (2020) 65-72.

6. Z. H. A. O.Li-ming, L. E. I.Li and L.I. U.Yu, The early-warning model based on BP artificial neural networks for enterprises, Jour. of NW SCI-TECH Uni. of Agri. and Fore, (2004) 3.

7. X. L.Ning, Y. F.Zhao and F.E.Chen, Index system and prosperity indices of global shipping industry and applied research, Journal of Shanghai Jiaotong University, 47(3) (2013).

8. S.M.Shellman and B.M.Stewart, Predicting risk factors associated with forced migration: An early warning model of Haitian flight, Civil Wars, 9(2) (2007) 174-199.

9. J.Shi, L.Qiu and L.Qi, Research on cruise economy prosperity index of Asia, In Report on the Development of Cruise Industry in China (2019) (pp. 103-116). Springer, Singapore (2020).

10. C.Wong, A framework for 'City Prosperity Index': linking indicators, analysis and policy, Habitat International, 45 (2015) 3-9. 
The Mechanism and Early-warning Value of ICT Enterprise Prosperity Index Based on Accounting Information

11. C.Wuzhao, Business cycle, industry prosperity and earnings management - empirical evidence from China's listed companies, Auditing Research, 5 (2013) 15.

12. Y.Yi and C.Yuan, Research on the dynamic monitoring of financial prosperity based on entropy model, In 2010 International Conference on E-Business and EGovernment (pp. 2519-2522), IEEE (2010).

13. B.Zeng, L.J.Qin, X.Yan, X.Q.Lin, S.Han L.K.Gao, The establishment and analysis of the prosperity indexes for China's power market, In 2nd Annual International Conference on Energy, Environmental \& Sustainable Ecosystem Development (EESED 2016). Atlantis Press, (2016). 